\title{
Идея сверхчеловека в творчестве М. Горького: рецепция ницшеанского Übermensch и социально-революционный порыв
}

\section{Д. А. Беляев}

Беляев Дмитрий Анатольевич, доктор философских наук, доцент кафедры философии, социологии и теологии, Липецкий государственный педагогический университет имени П. П. СеменоваТян-Шанского, dm.a.belyaev@gmail.com

Статья посвящена анализу художественно-образной объективации идеи сверхчеловека в литературном творчестве М. Горького. В исследовании поднимается проблема ницшеанства Горького, его рецептивного диалога с философией Ф. Ницше и семантического освоения концепта «Übermensch». Цель работы - выявление форм художественного воплощения идеи сверхчеловека и особенностей ее смысловой интерпретации в типических образах героев ранних произведений Горького. Констатируется, что в XIX - начале XX в. формируется новая, социально-революционная модальность конкретно исторической экспликации идеи сверхчеловека, получившая особую выраженность в дискурсе отечественной литературы критически-реалистической направленности. Компаративный семантический анализ работ Горького позволил обнаружить вполне определенное присутствие в нем отдельных ницшеанских мотивов и смыслов. В частности, их сближают темы нигилизма, преодоления «приземленности», культа свободы и деятельно-бунтарского порыва. Выявлено, что М. Горький сформировал свою, исторически актуальную социально ориентированную модель интерпретации ницшеанского Übermensch. Реконструированы и проанализированы две модели художественно-литературного воплощения идеи сверхчеловека - образно-символическая и социально-реалистическая. Формулируется вывод, согласно которому сверхчеловек у Горького по преимуществу понимается как ценностно и социально инаковый человек-революционер, устремленный к свободе через бунтарский нигилизм и ломку общественных стереотипов.

Ключевые слова: сверхчеловек, Горький, Ницше, Übermensch, свобода, нигилизм, русская литература.

DOl: https://doi.org/10.18500/1819-7671-2019-19-2-135-139

Идея сверхчеловека глубоко укоренилась в истории культуры. Она воплощает совокупность представлений о горизонте антропологической трансформации, а также об образе превосходного, совершенного или иномерного человека. Не случайно Б. Шоу отмечал, что сверхчеловек является «ровесником Прометея». Долгое время идея сверхчеловека оставалась феноменом исключительно мифологического, религиозномистического и эзотерического сознания. Однако в Новое время постепенно начинается ее социально-историческая объективизация. Идея сверхчеловека выходит за рамки мифотеологического культурного дискурса и, пусть пока во многом и имплицитно, осваивается как феномен социальной реальности. В контексте этой линии в XIX - начале XX в. формируется новая, социально-революционная модальность конкретно исторической экспликации идеи сверхчеловека.

Как культурный феномен он изначально появляется в дискурсе художественной литературы, которая в XIX столетии особенно явственно становится пространством ценностных и социальных рефлексий. И в этом качестве исключительное значение имеет творчество ряда отечественных писателей, ставшее зеркалом перспективного отражения передовых, пока еще полусознательных интенций, предчувствований и ожиданий, фундирующих становящийся дух социально-революционного обновленчества. Более того, русская литература XIX - начала XX в. сформировала особый рефлексивный дискурс осмысления идеи сверхчеловека, прежде всего, как аксиологического феномена, единицы пространства непосредственной и перспективной социокультурной практики.

В смысловом плане отечественное художественно-литературное осмысление идеи сверхчеловека шло в унисон с западноевропейской философской традицией, основным выразителем которой во второй половине XIX в. становится Ф. Ницше. Собственно, немецкий мыслитель определяет своего Übermensch, прежде всего, как аксиологического революционера, нигилиста и творца новых ценностей, что семантически вполне релевантно образам «новых людей» в творчестве М. Ю. Лермонтова, Н. Г. Чернышевского и $Ф$. М. Достоевского. Не случайно в ницшеведении уже с начала XX в. общим местом становится проведение параллелей между идеей сверхчеловека в философии Ницше и некоторыми персонажами (например, Родиона Раскольникова, Алексея Кириллова, Ивана Карамазова) романов Достоевского. Да и идейная перекличка героев Лермонтова с ницшеанским Übermensch была отмечена уже В. С. Соловьевым, также вполне очевидна некоторая внешняя близость «философии Рахметова» Чернышевского «философии сверхчеловека» 
Ницше. Однако творчество другого видного отечественного писателя, «буревестника революции» М. Горького совершенно незаслуженно зачастую исключается из широкого пространства художественно-литературной объективации идеи сверхчеловека. В этой связи особенно интересен и примечателен факт непосредственного «ницшеанского присутствия» в творчестве отечественного писателя. И здесь мы категорически не согласны с позицией Р. Т. Певцовой, которая утверждает, что «восприятие молодым Горьким «ницшеанских художественных установок» и принятие им идеи ницшеанского «сверхчеловека» - не что иное, как псевдонаучные размышления» [1, с. 6]. По нашему мнению, Горький создает особое художественно-литературное пространство репрезентации идеи сверхчеловека, которое основывается на модели ницшеанского Übermensch, но авторски переосмысленной в социально-революционной модальности с учетом культурно-исторического контекста реалий конца XIX - начала XX в. и общего «духа времени».

С одной стороны, известно, что Горький интересовался трудами Ницше и, как показывает Ю. П. Соколова, даже стилистически на уровне отдельных лингвоформ был близок немецкому философу, используя его «обороты речи и даже целые отрывки» [2, с. 107-108]. Л. А. Колобаева также констатирует несомненное идейное влияние эстетики Ницше на творчество молодого Горького [3, с. 165-166]. Более того, с 1899 г. Горький становится руководителем литературного кружка, изучающего творческое наследие Ницше. Не случайно уже в начале XX в. писателя называли «нашим “ницшеанцем-самородком”, сменившим в одиночку смиренное настроение своего времени на воинственную бодрость» [4, с. 19]. Сам Горький уже в 1930 г. в «Беседах о ремесле» подтверждает, что «снабдил» некоторых своих героев «коечем от философии Ницше» [5, с. 490-491]. С другой стороны, русский писатель преломляет отдельные идеи Ницше через призму собственной социально-героической семиосферы, что, в частности, рождает оригинальную социокультурно-антропологическую модель интерпретации идеи сверхчеловека.

Следует помнить, что творческая эволюция М. Горького включает в себя полярное отношение к философии Ф. Ницше. Например, уже в 20-30 гг. писатель упрекает его учение в «проповеди жестокости», апологетике рабства, которое категорически необходимо для «создания людей высшего типа - “сверхчеловеков”»
[5, с. 492-493]. Отчасти эта позиция была во многом продиктована спецификой идеологического контекста, сформированного в советской России, осудившим, а впоследствии и практически табуировавшим философию Ницше. Одновременно критический взгляд Горького на идеи немецкого мыслителя имеет, безусловно, и содержательно-смысловые основания. В частности, отечественный писатель как апологет социальной демократии и эгалитаризма, категорически не мог принять аристократических интенций Ницше [6, с. 81].

В конце XIX в. мировоззрению и творческой направленности Горького оказались созвучны некоторые идеи философии Ницше, которые писатель образно воплощает в своих героях. Условное ниищеанство Горького основывается на развитии им следующих тем: протест против буржуазной культуры, героический пафос, апологетика свободы, актуализация концепта «сильная личность» и нигилизм.

Несмотря на преобладание реалистической манеры художественного повествования в творчестве Горького, заметное место в образно-символическом оформлении авторской проекции идеи сверхчеловека занимает небольшой рассказ «Песня о Соколе», пронизанный глубоким символизмом. Есть все основания полагать, что «Песня о Соколе» написана Горьким под непосредственным влиянием идей Ницше и, в частности, философской притчи «Так говорил Заратустра». Например, Сокол и Уж - главные герои рассказа - фактически являются выразителями ницшевской идеи amor fati. Также известно, что на начальном этапе продумывания рассказа Горький избирает своим героем орла, а не сокола, а это, в свою очередь, является уже прямым пересечением с сюжетом об орле и змее из «Заратустры».

Итак, в «Песне о Соколе» храбрый и свободный Сокол противопоставлен приземленномy, практичному и по-своему мудрому «земли творенью» - Ужу. Основной конфликт рассказа раскрывается через разность деятельного отношения и жизненного целеполагания героев. Так, рационально мыслящий Уж резонно полагает: «Летай иль ползай, конец известен: все в землю лягут, все прахом будет» [7, с. 153]. Однако Сокол находится за рамками этой логики «фатального равенства», для него форма деятельного проживания определяет смысл жизни, а не ее неизбежный конец. Для Сокола жизнь - это героическая борьба, преодоление и полет, для Ужа - спокойствие и сытый комфорт ползанья по теплой земле. 
Симптоматично, что жизненная энергетика Сокола, его «тяга к небу» провоцирует в Уже размышления о смысле, возможно, заключенном в полете. «Должно быть, в небе и в самом деле пожить приятно, коль он так стонет!» [7, с. 153]. Однако в ходе эксперимента Уж совершает деятельную подмену полета его симуляцией, на основе чего выстраивает ложную критику жизненной модели Сокола, перерождаясь из рассудительного мудреца в «образец обывательской ограниченности» [2, с. 126]. Через образ Сокола Горький прославляет «безумство храбрых», которые живут волей к борьбе, полету и свободе. Также в конце рассказа автор наполняет общественным смыслом жертвенность и гибель Сокола, которая в перспективе окажется способна «зажечь безумной жаждой свободы» «много смелых сердец» [7, с. 155], т.е. совершить переворот в сознании масс относительно основных жизнеполагающих ценностей.

В целом художественный концепт «сокол» как сверхчеловеческая метафора, героизирующая деятельную жизненную модель как континуум перманентных актов волевых преодолений, нашел отклик и прочно укоренился в пространстве современной культуры. Символ стремления к полету, обретению способности летать оказывается релевантен образу преображенного (лучшего) человека, стремящегося к преодолению наличной приземленности. Это символическое описание деятельной модели «нового человека» нашло свое развитие в реалистической прозе писателя. В ранних рассказах М. Горького происходит становление концепта «сильная личность», основой которого являются тяга к абсолютной свободе, независимости, агрессивность и до некоторой степени нигилизм и асоциальность. Все эти характеристики в той или иной степени присущи таким художественным персонажам, как Челкаш, Зобар, Рада, Мальва, Силан. Обращает на себя особое внимание то, что преступление как деятельное воплощение предельного асоциального поведения для этих героев оказывается, как точно отмечает Ю. П. Соколова, «свидетельством жизненной силы» [2, с. 111]. То есть общественные нормы, традиционная этика определяются ограничителями «полноты жизни», а через их преступление происходит становление «настоящего человеческого начала» и утверждение свободы, являющейся высшей ценностью для всех этих героев. Также, пусть и не акцентированно, присутствует мысль, что и вера в Бога как высший нравственный Абсолют есть фактор ограничения «жизненной силы» человека. Здесь важны ценностные приоритеты, которые расставляют герои Горького - «жизненная свобода», дающая «полноту жизни», оказывается важнее общественно-традиционной («рабской») морали.

Особенно рельефно и показательно, на наш взгляд, сравнение двух главных героев рассказа Горького «Челкаш». Челкаш - «ловкий, смелый вор» и «заядлый пьяница» олицетворяет «свободного человека» [7, с. 119-120]. Он показан Горьким нарочито «хищно» и агрессивно, что усиливает его сопоставление с ястребом. Гаврила - скромный и боязливый крестьянин, пришедший в город на заработки. Внешне он тоже силен, но его сила иного рода, нежели у Челкаша, она носит приземленный характер. В ней нет реактивности, жизненной экспрессии и свободы. Всегда пределом его свободы, даже в мечтах, является Бог, а само пространство свободы и одновременно несвободы создается деньгами, что в конечном счете делает его в глазах Челкаша «жадным рабом» [7, с. 147].

Само именование Гаврилы «рабом» подразумевает, что Челкаш оказывается «господином». Собственно главным атрибутом данного господства является пространство свободы, в котором находится Челкаш. Это возвышает его в своих глазах и наполняет «жалостью и ненавистью» по отношению к «рабу» [7, с. 146]. Между тем сам Гаврила, несмотря на страх и некоторый пиетет перед Челкашем, констатирует «ненужность его на земле». Именно это понимание «человеческого превосходства» и одновременно социокультурной ненужности «сверхчеловеков» создает драматический диссонанс в творчестве Горького и по-новому проблематизирует идею сверхчеловека.

Символическое перекодирование и считывание ситуации конфликтности данных героев, как и в случае «Песни о Соколе», позволяет говорить об архетипическом столкновении двух начал - воздуха и земли. Воздух - это свобода и независимость, легкость полета и жизненная энергетика. Земля - традиция, укорененность, рождающая в понимании Горького ограниченность и несвободу. Фактически противостояние Челкаша и Гаврилы - это столкновение свободы и несвободы в пространстве социокультурной реальности, и моральную победу одерживает свобода, т.е. новая, в сравнении с традиционной, ценностная модель, возвышающая новый тип героя и «лучшего» человека вообще.

Одновременно с этим герои Горького существуют в приземленно-реалистичной бытовой действительности. Они являются субъектными репрезентаторами конкретной социокультурной 
реальности, что обеспечивает возможность непосредственного проецирования и конвертирования деятельной матрицы этих героев в контекст непосредственной культурной реальности. Это создало огромный потенциал для конкретноисторической актуализации данных сверхчеловеческих типажей Горького.

На наш взгляд, Горький довольно чутко уловил ценностно-антропологическую точку надлома современной ему культуры и предпринял попытку ее художественно-образного исследования, в результате чего был сформирован литературный дискурс «рассказов о новом человеке», призванный стать социокультурным прогрессором. Очевидна авторская уверенность, что именно новая духовно-ценностная конституция человека, основой которой будут свобода, воля, абсолютность Я, социокультурный нигилизм, станут условием рождения нового, превосходно человеческого. Соответственно сверхчеловек понимается по преимуществу как ценностно и социально инаково-трансгрессивный человекреволюционер.

В целом художественные образы Сокола и «свободного босяка» Горького являются, на наш взгляд, отражением революционного духа времени и актуальных социокультурно ориентированных антропологических исканий. Более того, отчасти именно они фундировали вскоре сформировавшийся концепт «советского человека», который стал новой страницей в истории культурной феноменологии идеи сверхчеловека в ситуации радикальной революционно-социалистической трансформации. И в этом смысловом измерении вполне можно согласиться с Т. Манном, видевшим в творчестве Горького своеобразную тропу, ведущую от Ницше к советскому социализму, где также сформировалась особая модальность культурной объективации идеи сверхчеловека.

\section{Список литературы}

1. Певциова Р. Т. М. Горький и Фридрих Ницше. М., 2001. $65 \mathrm{c}$.

2. Соколова Ю. П. Архетип «Ницше» в русской литературе 1890-1910 гг. : дис. ... канд. филол. наук. Магнитогорск, 2002. $170 \mathrm{c.}$

3. Колобаева Л. А. Горький и Ницше // Вопр. литературы. 1990. № 10. С. 162-173.

4. Лихтенберже А. Философия Ницше. СПб., 1901. 144 с.

5. Горький М. О литературе. М., 1953. 868 с.

6. Кулагина Г. Н. Культурно-этический идеал сверхчеловека. Ницше и творчество М. Горького // Философские аспекты культуры. Казань, 1993. С. 80-82.

7. Горький М. Собр. соч. : в 16 т. М., 1979. Т. 1.432 с.

\section{Образец для цитирования:}

Беляев Д. А. Идея сверхчеловека в творчестве М. Горького: рецепция ницшеанского Übermensch и социально-революционный порыв // Изв. Сарат. ун-та. Нов. сер. Сер. Философия. Психология. Педагогика. 2019. Т. 19, вып. 2. C. 135-139. DOI: https://doi.org/10.18500/1819-7671-2019-19-2-135-139

\section{The Idea of the "Overman" in M. Gorky's Creative Work: the Reception of the Nietzschean Übermensch and the Social Revolutionary Impulse}

\section{A. Belyaev}

Dmitriy A. Belyaev, https://orcid.org/0000-0002-8062-1039, Lipetsk State Pedagogical P. Semenov-Tyan-Shansky University, 42 Lenin St., Lipetsk 398020, Russia, dm.a.belyaev@gmail.com

The article is devoted to the analysis of the artistic-figurative objectification of the idea of the Overman in M. Gorky's literary works. The study addresses the problem of Gorky's Nietzscheanism, his receptive dialogue with F. Nietzsche's philosophy and the semantic development of the Übermensch concept. The aim of the work is to identify the forms of artistic embodiment of the Overman idea and the peculiarities of its semantic interpretation in typical characters of Gorky's early works. In the course of the research it is stated that in the XIX - early XX century a new, socially revolutionary modality of a concrete historical explication of the Overman idea is formed, and has received its special manifestation in the discourse of the national literature of the critical-realistic orientation. The comparative semantic analysis of Gorky's works allowed the discovery of the quite definite presence of the individual Nietzschean motifs and meanings in it. In particular, they are brought together by the themes of nihilism, overcoming of everydayness - the cult of freedom and - the rebellious impulse. It was also brought out that Gorky had formed his historically relevant socially oriented model for the interpretation of the Nietzschean Übermensch. Two models of artistic and literary embodiment of the Overman idea were reconstructed and analyzed. They are the image-symbolic and social-realistic models. In conclusion of the study, we can say that Gorky's Overman is primarily understood as a value-driven and socially different revolutionary man, striving for freedom through rebellious nihilism and breaking - social stereotypes.

Keywords: overman, Gorky, Nietzsche, Übermensch, freedom, nihilism, russian literature.

\section{References}

1. Pevtsova R. T. M. Gorkiy i Fridrikh Nitsshe [Gorky and Friedrich Nietzsche]. Moscow, 2001. 65 p. (in Russian). 
2. Sokolova Yu. P. Arkhetip «Nitsshe»v russkoy literature 1890-1910 gg. [The Nietzsche Archetype in Russian Literature of 1890-1910]. Diss. Cand. Sci. (Philol.). Magnitogorsk, 2002. 170 p. (in Russian).

3. Kolobaeva L. A. Gorky and Nietzsche. Voprosy literatury [Literature Questions], 1990, no. 10, pp. 162-173 (in Russian).

4. Likhtenberzhe A. Filosofiya Nitsshe [Nietzsche's Philosophy]. St. Petersburg, 1901. 144 p. (in Russian).
5. Gorkiy M. O literature (About Literature). Moscow, 1953. 868 p. (in Russian).

6. Kulagina G. N. Cultural and Ethical Ideal of Overman. Nietzsche and the Works of M. Gorky]. In: Filosofskie aspekty kultury [Philosophical Aspects of Culture]. Kazan, 1993, pp. 80-82 (in Russian).

7. Gorkiy M. Sobr. soch.: v 16 t. [Complete works: in 16 vols.]. Moscow, 1979, vol. 1, 432 p. (in Russian).

\section{Cite this article as:}

Belyaev D. A. The Idea of the "Overman” in M. Gorky's Creative Work: the Reception of the Nietzschean Übermensch and the Social Revolutionary Impulse. Izv. Saratov Univ. (N. S.), Ser. Philosophy. Psychology. Pedagogy, 2019, vol. 19, iss. 2, pp. 135-139. DOI: https://doi.org/10.18500/1819-7671-2019-19-2-135-139 